\title{
Dislocating the Eschaton? Appraising Realized Eschatology
}

\author{
Mikel Burley ${ }^{1}$
}

Published online: 14 May 2016

(C) The Author(s) 2016. This article is published with open access at Springerlink.com

\begin{abstract}
Was Jesus Christ a deluded prophet who expected an imminent collapse of the world followed by the dawning of a kingdom that has never eventuated? Some who reject Christianity think that he was, and as a consequence are highly suspicious about any other claims that are attributed to Jesus. However, other interpretations of the apparently eschatological pronouncements in the New Testament exist, one of which is realized eschatology, this being the idea, roughly, that the kingdom or reign of God was realized in or through the ministry of Jesus itself. Debates surrounding the competing interpretations of New Testament eschatology raise fascinating issues, both exegetical and conceptual. Exploring some of these issues from the perspective of philosophy of religion, informed by theological and biblical studies, this article argues that realized eschatology is a religious option that, contrary to common criticisms, is neither incoherent nor implausibly reductive.
\end{abstract}

Keywords Eschaton-Realized eschatology C.H.Dodd·RudolfBultmann-Kingdom of God · Jesus Christ

[The] declaration that the Kingdom of God has already come necessarily dislocates the whole eschatological scheme in which its expected coming closes the long vista of the future. The eschaton has moved from the future to the present, from the sphere of expectation into that of realized experience (Dodd 1936b: 50).

The essential thing about the eschatological message is the idea of God that operates in it and the idea of human existence that it contains - not the belief that the end of the world is just ahead (Bultmann 1952: 23).

Mikel Burley

m.m.burley@leeds.ac.uk

1 School of Philosophy, Religion and History of Science, University of Leeds, Leeds LS2 9JT, UK 
Eschatology - the doctrine of, or discourse about, the last things - has both a teleological and a temporal sense. That is, the 'end' with which eschatology is concerned can be the purpose or goal as well as the terminus ad quem, the endpoint towards which human life or history more generally is heading (cf. Walls 2008a: 4; 2010: 78). This teleological sense, provided it is not construed in unduly narrow temporal terms, facilitates a multiplicity of ways of understanding eschatology within both the context of Christian theology and that of other religious traditions. Analytic philosophy of religion has not always acknowledged this multiplicity, tending instead to make certain quick assumptions about what eschatology 'must' be. Some have suggested that eschatology must presuppose a conception of history as moving towards an endpoint or a conception of personal survival beyond death, or both of these conceptions together. ${ }^{1}$ These are, of course, prevalent eschatological themes, yet they are neither universally accepted among all those who have eschatological beliefs nor are they doctrinally unambiguous; being open to interpretation, their analysis requires attention to particularities and distinctions that are often glossed over.

This article examines the eschatological orientation most commonly known as realized eschatology, which, though much discussed in Christian theology and biblical studies, has been largely neglected in analytic philosophy of religion. My purpose is not to establish the truth or falsity of the orientation in question, but to assess its intelligibility - its meaningfulness as a religious possibility, especially with regard to its way of understanding the person and 'event' of Jesus Christ and the message or kerygma that is attributed to him.

Coined by C. H. Dodd in his 1935 book, The Parables of the Kingdom, 'realized eschatology' denotes, in the first instance, an interpretation of the New Testament according to which the coming of the kingdom or reign of God is not something that would occur only after the completion of Jesus' ministry; rather, it was brought into reality (realized, actualized) during that ministry itself. For Dodd, there is no question about whether Jesus declared that 'the eschaton, the divinely ordained climax of history, is here' (1936b: 193), ${ }^{2}$ for the declaration is evident both implicitly in many of Jesus' parables and explicitly in various statements ascribed to Jesus in the gospels. ${ }^{3}$ Some other scholars, meanwhile, draw a distinction between the Jesus of the synoptic gospels, whom they consider to be portrayed as an apocalyptic prophet who did indeed regard the kingdom as imminent rather than already present, and the Jesus whose status as the 'eschatological event' begins to be elucidated in more definitive terms first in the epistles of Paul and then, even more emphatically, in the Johannine gospel and epistles.

Exemplary of the latter view is Rudolf Bultmann, who, while not himself using the term 'realized eschatology', speaks of the earthly ministry of Jesus, combined with the acceptance of Jesus' message in the faith of his followers, as 'the Revelation of God's "reality" (1955: 58). Since Bultmann maintains that this revelation, especially as narrated by John the Evangelist, is one that 'radically transposed eschatological occurrence into the present'

\footnotetext{
1 'The common assumption of all eschatology is that human life and/or history are moving in a certain direction, towards a certain end or goal ... . Accordingly, circular views of history, or even linear views of time with no envisaged afterlife or end-state, have no eschatology' (Davis 1998: 413-414). See also work by John Hick, whose notion of 'eschatological verification' is a rare exception to the scarce discussion of the term 'eschatology' in philosophy of religion. He insists that this notion 'can make sense ... only if the logically prior idea of continued personal existence after death is intelligible' (1966: 178-179).

${ }^{2}$ I shall be quoting from the November 1936 edition of The Parables of the Kingdom. A revised edition was published in 1961 with a new preface, but the content of the passages to which I refer remained unchanged.

${ }^{3}$ See esp. Matthew 3:2; 4:17; 10:7; 12:28; Mark 1:15; Luke 11:20.
} 
(79), it is hardly surprising that Bultmann's name and ideas are commonly cited in discussions of realized eschatology. ${ }^{4}$ While remaining mindful of differences between Bultmann's own 'existentialist' emphasis and the approaches of Dodd and others, I shall also be bringing his ideas into consideration here. ${ }^{5}$

My discussion proceeds as follows. I begin by explaining how the concept of realized eschatology is relevant to debates about the notion of eternal life, with particular reference to the idea of eternal life as an exclusively present possession as opposed to a life subsequent to death that continues on forever. I then introduce the concept of eschatology more fully, focusing especially on the problem emerging from the fact that Jesus Christ, as presented in the synoptic gospels, appears to have prophesied an imminent apocalypse that did not eventuate. This will be followed by exposition and critical discussion of realized eschatology in particular, which constitutes a possible response to the aforementioned problem. By offering replies to four types of objection, I argue that realized eschatology is a religious option that, contrary to some of the common criticisms, is neither incoherent nor implausibly reductive.

By discussing realized eschatology from the perspective of philosophy of religion, but in a way that is informed by debates in theology and biblical studies, I aim to contribute not only to an enhanced understanding of this concept in particular, but also to the advancement of interdisciplinary working in the philosophy of religion more broadly. It has not gone unnoticed by some of its own practitioners that philosophy of religion in an analytic style often operates with an unhelpfully narrow sphere of reference. Instead of grappling with fully ramified religious beliefs in all their complexity and messiness, many philosophers make do with pared down concepts such as 'bare theism' or 'standard theism' - 'theism as abstracted from the peculiarities of any particular religious tradition' (Wainwright 2013: 54). ${ }^{6}$ This penchant for abstraction, though often useful and perhaps sometimes necessary, runs the risk of neglecting the variety of forms that religious beliefs, not least beliefs in God, can and do take. ${ }^{7}$ Among the methods available to those who wish to avoid an oversimplifying approach is that of bringing philosophy of religion into engagement with intersecting disciplines such as theology and the study of religious scriptures. At the forefront of the recent exploration of these methods have been Marilyn McCord Adams, who urges 'philosophers to be more theological' and theologians to define issues 'in a philosophical way' (2006: ix), and Eleonore Stump, who 'draw[s] on the insights of [biblical] narratives' in order to escape the 'aridity' of much Anglo-American philosophy of religion $(2010: 23,25){ }^{8}$ I

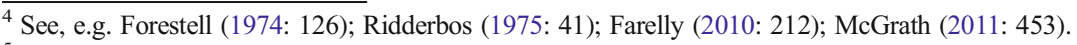

${ }^{5}$ Commentators sometimes claim there to be a 'fundamental difference' between Bultmann and Dodd, on the grounds that 'for Dodd, the eschaton is realized in the coming of Christ, whereas, for Bultmann, it is realized in the preaching of the kerygma in the present' (Wondra and Wondra 2002: 236). As will be evident from parts of my discussion, I regard this claim as exaggerated.

${ }^{6}$ For instances of the term 'bare theism', see Swinburne (2008: 23) and Philipse (2012: 145). For 'standard theism', see Rowe (1984: 95). Wainwright, it should be noted, is not endorsing the idea that philosophers of religion ought to examine only abstract conceptions of theism; he in fact argues that, in certain respects, a more elaborated religious tradition, such as Christianity, is more rationally defensible than 'bare theism'.

${ }^{7}$ For some particularly good critical work on this theme, see Citron $(2012,2013)$.

8 '[T] hose more sympathetic to other traditions in philosophy have regularly complained about what they call "the aridity" or "the narrowness" of Anglo-American philosophy; and, in my view, this reproach is not altogether unjustified' (Stump 2010: 23).
} 
hope to further those aspirations both here and in the larger project of which this article is an integral part.

\section{Eternal Life and the Problem of Jesus}

There has been a long-running debate among philosophers, certainly not limited to philosophers of religion, over whether immortality is desirable or whether, owing to certain ineradicable features of a recognizably human life, immortality could only end up being intolerably tedious, even meaningless. ${ }^{9}$ My own contribution to this debate has been to argue that the conception of immortality in play has not been sufficiently well defined by the various disputants (Burley 2009, 2015). The arguments for and against the desirability or meaningfulness of immortality are generally based on thinly described fictional scenarios or thought-experiments, which serve to isolate the concept of immortality from precisely the circumstances in which talk of immortality or eternal life gains the sense that it has-circumstances that, first and foremost, are deeply embedded in religious forms of life.

An assumption shared by participants on both sides of the debate over immortality is that terms such as 'immortality' and 'eternal life' imply 'living forever' or living a life that is 'infinitely long' (see, e.g. Fischer and Mitchell-Yellin 2014; Chappell 2009), and this same assumption is often made in the philosophy of religion. However, not only does the notion of 'living forever' tend to remain seriously under-described: the assumption is also questionable. Indeed, many theologians and some philosophers have questioned it, arguing that religious traditions, not least Christianity, harbour resources for articulating conceptions of eternal life that are not merely consistent with an acceptance of the finality of death, but which, in at least some instances, are internally related to that acceptance. The internal relation derives from the fact that contemplating one's finitude - fully recognizing one's mortality - is one of the circumstances through which an appreciation can emerge of life as a spiritual and ethical task, a task that demands living in obedience to certain values lest the precious gift of life that one has been given be poorly received. For a Christian, those values, especially as expressed in the Johannine writings, involve replacing a desire for recognition by the world with a commitment to love one another as one is loved by God in Christ (1 John 2:15; John 13:34); it is in this that faith in Jesus Christ consists (1 John 3:23), and in faith one has eternal life (John 3:36; 6:47).

Some version of this notion of eternal life as a present possession has been endorsed, albeit often in equivocal terms, by theologians and religious thinkers from various traditions of Christian thought. ${ }^{10}$ Friedrich Schleiermacher, for instance, at the end of his speeches on religion declares 'the goal and the character of the religious life' to be 'not the immortality desired and believed in by many', but rather a form of immortality that is available to us 'in this temporal life': 'In the midst of finitude to be one with the Infinite and in every moment to be eternal is the immortality of religion' (1958: 101). In the twentieth century, the Reformed theologian Karl Barth wrote of eternal life that it 'is not another and second life,

\footnotetext{
${ }^{9}$ The starting point for much of the debate since the 1970s has been a well-known and frequently anthologized essay by Bernard Williams (1973).

${ }^{10} \mathrm{I}$ consider it at greater length in Burley (forthcoming).
} 
beyond the present one. It is this life, but the reverse side which God sees although it is as yet hidden from us' (1981: 9). ${ }^{11}$ The 'as yet' might be taken to imply that there will come a time when this other aspect of our lives is disclosed to us, were it not for Barth's insistence elsewhere that 'Death is intrinsically the end and limit of human life' (1960: 588). Eternal life, for Barth, is one's finite and mortal life in its relationship with God through Christ; although we die, 'we are not lost to Him' (1960: 610; cf. 1981: 9). Meanwhile, the Jesuit theologian Karl Rahner has used the image of 'radical interiority' to describe eternal life. It is not a continuation of life on the other side of death, but is the 'interiority ... of [our] personal history of freedom', the sum of our choices and actions, 'which death cannot take away' (Rahner 1975: 175; 1986: 88; cf. 1966: 347).

One of the major stumbling blocks for anyone who wants to argue, within a broadly Christian framework, for a conception of eternal life as an exclusively present possession is that, whatever might be said about the finitude of our own lives, it can hardly be denied that the belief that at least one man has been raised and entered into a renewed life beyond death is essential to Christian faith; and 'as Christ was raised from the dead by the glory of the Father, we too might walk in newness of life' (Romans $6: 4^{12}$ ). If this is the Easter hopethat we, like Jesus, will be raised in glory after death - then it is hard to see how a coherent account can be given within Christian parameters of an eternal life that, as D. Z. Phillips has put it, 'is not more life, but this life seen under certain moral and religious modes of thought' (1970: 49). Are we not forced to admit that, at least as far as Christianity is concerned, the philosophers have been right to take it for granted that immortal or eternal life is a life that goes on forever?

This is where the concept of realized eschatology comes in, as it opens up the possibility of an alternative vision not only of eternal life in general, but of the life, death and resurrection of Jesus Christ in particular; it strongly implies, even if the implication only occasionally emerges into explicit contention, that there is a way of understanding Jesus' own life as mortal and finite, without its essential salvific role thereby being diminished. According to realized eschatology, the life and message of Jesus embodies a transformed conception of what blessedness and salvation, resurrection and eternal life, consist in. God's opposition to evil is exhibited not in the physical defeat of those who commit it, but in the very suffering that evil inflicts; it is in that suffering that evil displays itself as evil, and it is in stark contrast with the love of God revealed in Christ that sin displays itself all the more vividly as sin. There is no crushing of enemies in this re-envisaged eschatological kingdom, but 'a new view of what it means for God's righteousness to be manifested, and for sin to be condemned' (Dodd 1936b: 79).

Before saying more about realized eschatology in particular, I shall introduce the concept of eschatology more broadly and outline the kind of eschatological interpretation to which realized eschatology is, in large part,

\footnotetext{
${ }_{11}$ This passage occurs in a letter to Werner Rüegg, 6 July 1961. For an alternative translation, see Hebblethwaite (1979: 57): 'Eternal life is not another, second life beyond our present one, but this one, in its as yet hidden reverse side, as God sees it - in its relation to what He in Jesus Christ has done for the whole world and so for us'. For further discussion of the passage, see Hitchcock (2013: 133).

12 The Holy Bible: Revised Standard Version [RSV] (1971).
} 
responding. As we shall see, this other eschatological interpretation presents Christian apologists with the apparently disastrous conclusion that Jesus was a deluded apocalyptic prophet.

\section{Eschatology and the Challenge of the 'Monstrous Illusion'}

The earliest use of the term 'eschatology' recorded in the Oxford English Dictionary (2013) is from 1845. This appears not to be the very first occurrence of the term, as the author in question - Professor George Bush of New York City University-uses it as though it will be familiar to his readers, but it is probably among the earliest uses. Bush refers to 'scriptural eschatology, or the doctrine of the last things' (Bush 1845: v; original emphasis), and 'doctrine of last things' has remained the standard way of explicating the term.

Although 'eschatology' has been adopted in discussions of religions other than Christianity (see, e.g. Walls 2008 b, chs 6-10), ${ }^{13}$ it is its application in Christian contexts with which I am concerned in this article. In these contexts the term typically encompasses 'the doctrines of physical death, the intermediate state, the second coming of Christ, the resurrection, the last judgment and the final states of the righteous and wicked' (Aune 1972: $1 \mathrm{fn} .1$ ). The adjectives that have been used to qualify different varieties of eschatology are numerous. Aside from the commonplace 'apocalyptic eschatology', divisible into the 'eschatology of woe' and the 'eschatology of bliss' (Dodd 1936b: 71-72), further examples include the following: 'ethical eschatology' (Schweitzer 1914: 115; Crossan 1998: 287), 'futuristic eschatology' (Kümmel 1963), 'inaugurated eschatology' (Florovsky 1972: 36; Hunter 1973: 94-96), ${ }^{14}$ 'philosophical eschatology' (Dhavamony 1999: 255), 'potentially present eschatology' (Caragounis 2001: 130-131), 'present [or presentist] eschatology’ (Ellis 1965; cf. Kümmel 1959), 'proleptic eschatology' (Martin 1939), ${ }^{15}$ 'sublimated eschatology' (Martin 1939: 88) and 'transmuted eschatology' (Dobschütz 1910: 150). Most of these, and others, bear in some way upon our present topic, but to discuss each of them would take us too far afield. Of more immediate relevance is a position to which realized eschatology is in large part a response, generally known in English as 'consistent' or 'thoroughgoing' eschatology.

The latter terms are translations of the German konsequente Eschatologie, which was coined in the early years of the twentieth century by Albert Schweitzer, who is well known for, among other things, his 1906 book The Quest of the Historical Jesus. ${ }^{16}$ Although its consistency and thoroughness have been questioned, ${ }^{17}$ consistent

\footnotetext{
${ }_{13}$ See also Taylor (1968); Hiltebeitel (1972); Hanson (1979); Obeyesekere (1980); Smith and Haddad (1981); Zürcher (1982); Dhavamony (1999, ch. 10). The assumption is still often made, however, that eschatology is specifically a 'branch of Christian theology' (Walls 2010: 78).

${ }^{14}$ Cf. Robinson (1957: 29-30), commenting on Acts 2:32-36: 'We have here what might be called a fully inaugurated eschatology. All is not yet summed up; yet all that is to be has now been set in motion'.

${ }^{15}$ Cf. Fuller (1954: 50): 'The powers of the Kingdom are proleptically operative in Jesus, although its coming remains a decisive act of the future'.

${ }^{16}$ The original German title was Von Reimarus zu Wrede. Eine Geschichte der Leben-Jesu-Forschung (Schweitzer 1906), literally 'From Reimarus to Wrede: a history of life-of-Jesus-research'.

17 'It is doubtful ... that it was either consistent or thoroughgoing, but the name has stuck' (Harkness 1974: 32).
} 
eschatology is so called because it seeks in a consistent and thoroughgoing manner to explain 'the whole public work of Jesus' in relation to his eschatological worldview (Schweitzer 1911: 349). The result is a depiction of Jesus as an apocalyptic prophet, whose expectation of imminent world destruction and the subsequent dawning of a new kingdom makes him, in Schweitzer's phrase, 'a stranger to our time' (399).

The problem raised for those who take consistent eschatology seriously is that Jesus appears to have been not merely mistaken, but massively deluded about what would occur within the lifetimes of at least some of the people with whom he worked and spoke. 'Truly, I say to you', he declares in the Gospel of Mark, 'there are some standing here who will not taste death before they see that the kingdom of God has come with power' (9:1 [RSV]). ${ }^{18}$ If, as most people believe, the kingdom of God did not come with power prior to the deaths of those who heard Jesus' words - and, moreover, has still not come to this day-then it would appear that Jesus was wrong. As Martin Dibelius strikingly puts it in a book first published in 1939, 'It still looks as though a monstrous illusion lies at the basis of the whole mission of Jesus, the illusion of something immediately impending which actually never has come to pass' (1949: 70).

The worry for many is that if Jesus was so monstrously wrong about the coming of the kingdom, how can we be sure that he was not wrong about many other things as well? Could he not have had an illusory conception of God? ${ }^{19}$ Might his ethical teachings not have been dangerously misguided, especially given that, on many interpretations, they are profoundly interwoven with the expectation of an imminent cataclysm? ${ }^{20}$ Among those who have expressed precisely this latter worry is Bertrand Russell, who remarks of Jesus in his famous essay 'Why I Am Not a Christian', ${ }^{21}$ that "When He said, "Take no thought for the morrow", and things of that sort, it was very largely because He thought that the second coming was going to be very soon, and that ordinary mundane affairs did not count' (1957: 16). ${ }^{22}$ 'In that respect', Russell adds, 'clearly He was not so wise as some other people have been, and He was certainly not superlatively wise' (17).

\section{Responding to the Challenge of the Monstrous Illusion}

There are various ways of responding to the challenge posed by consistent eschatology's picture of Jesus as an apparently over-imaginative apocalyptist. One

\footnotetext{
${ }^{18}$ Cf. Matthew 16:28; Luke 9:27. See also Weiss (1971: 91): 'Whatever uncertainty there may be as to the exact time of the Second Coming, it is only conceivable within the lifetime of the generation among which Jesus worked'.

${ }^{19}$ As Bultmann (1952: 22) puts it, 'in view of the fact that the proclamation of the irruption of God's Reign was not fulfilled - that is, that Jesus' expectation of the near end of the world turned out to be an illusion - the question arises whether his idea of God was not also illusory'.

20 'Jesus' ethical teaching is not a separate body of moral instructions, but rather part of his preaching of the eschatological in-breaking of the reign of God, which demands a total and immediate response from his hearers' (Burridge 2007: 48).

${ }^{21}$ First delivered as a lecture to the South London Branch of the National Secular Society at Battersea Town Hall, 6 March 1927.

22 Russell is quoting Matthew 6:34, which reads, in the King James Version, 'Take therefore no thought for the morrow: for the morrow shall take thought for the things of itself. Sufficient unto the day is the evil thereof' (The Bible: Authorized King James Version 1997).
} 
way, of course, is to follow Russell in rejecting Christianity as false or confused. Another way is to recognize the compresence in Jesus' teachings of two distinguishable 'streams' or 'currents': the apocalyptic vision on the one hand and a 'radicalized wisdom teaching' on the other, the latter including injunctions such as that of loving not only one's neighbours but also one's enemies (Matthew 5:43-47), which injunctions seem not to be directly related to apocalyptic expectations (Windisch 1951: 40-41). A third way, which is in many respects the most interesting, is to undertake a revised interpretation of the supposedly apocalyptic vision itself, to see whether sense can be made of it that avoids characterizing Christianity as being founded upon a colossal error.

A number of reinterpretive strategies have been deployed, most of which attempt to read at least some of the apparently future-oriented proclamations of the gospels as being really, or primarily, concerned with the present. In short, they attempt, in Dodd's provocative phrase, to 'dislocate' the eschaton, moving it 'from the future to the present, from the sphere of expectation into that of realized experience' (1936b: 50). Although a number of earlier biblical scholars had anticipated many of the relevant lines of interpretation, ${ }^{23}$ it is Dodd's The Parables of the Kingdom that both employs the term 'realized eschatology' for the first time and which argues concisely and compellingly in favour of this idea, earning it a place as 'one of the most influential books ever published in New Testament studies’ (Sullivan 1988: 4).

As the title of his book suggests, Dodd includes as part of his interpretive argument an account of numerous parables that occur in the gospels. Among these are somemost notably the parables of the faithful and unfaithful servants, the waiting servants, and the thief in the night - that are commonly construed as 'eschatological' parables. They emphasize the need to remain awake and watchful, to prevent one's being caught unawares when the momentous time arrives. 'Keep awake then', says Jesus in the Gospel of Mark, 'for you do not know when the master of the house is coming, late in the evening, or at midnight, or at cockcrow, or at dawn: lest he should come and find you asleep. And what I say to you, I say to all: keep awake' (Mark 13:35-37, quoted in Dodd 1936b: 161). ${ }^{24}$

How one interprets an injunction such as this hinges upon what one takes the momentous event for which one is waiting to be. According to standard, 'futuristic', interpretations, the event is the return in glory of the Lord Jesus Christ after a period of absence (see, e.g. Owen 1959: 179). According to Dodd, meanwhile, it is the conflict that Jesus and his followers are going to have to face when the authorities crack down on them, as they inevitably would. Although Jesus does not specify in the parables the form that the impending crisis will take, he is urging his audience to be prepared for whatever may come (Dodd 1936b: 202).

Beyond the immediate context of the persecution that will befall Jesus and his disciples, Dodd acknowledges that the injunction to keep awake has the broader

\footnotetext{
${ }^{23}$ Sullivan (1988: 4-5) cites Sharman (1909) as one instance. A list of other precursors might include Muirhead (1904); Dobschütz (1910) and Manson (1931). For concise overviews, see Ladd (1974: 11-14). Perhaps most important is Otto (1934), to whose work Dodd expresses indebtedness (Dodd 1936b: 38 fn.1); but for the suggestion that Dodd's appreciation of Otto's work is unduly selective, see Fuller (1954: 20 fn.1). ${ }^{24}$ Cf. Luke 12:37-38 [RSV]: 'Blessed are those servants whom the master finds awake when he comes; ... If he comes in the second watch, or in the third, and finds them so, blessed are those servants!'
} 
significance of remaining ever vigilant, both as individuals and as human societies, for challenges that call us, as Dodd puts it, to discern the 'eternal' or 'divine significance of events' (1936b: 205). He speaks of Jesus' having brought to us 'the hour of decision' (1936b: 198, 204), by which Dodd seems to mean something similar to what Bultmann (1952: 9) is getting at when he describes Jesus as signifying 'the demand for decision' at the final hour, an expression that in turn echoes Søren Kierkegaard's notion of the 'eleventh hour' (Kierkegaard 1956, esp. ch. 2). This idea of a decision at the eleventh hour is intended to accentuate the urgency of seizing the moment, of holding fast to a set of values and a way of life or, to invoke a phrase from Ludwig Wittgenstein (1980: $64 \mathrm{e}$ ), of passionately committing oneself 'to a system of reference'.

For the Christian, 'the question', as Bultmann puts it, 'is whether [one] really desires God and His Reign or the world and its goods' (1952: 9). For Kierkegaard, it is a matter of cutting through 'the rush of busyness' that normally serves to distract us from our own finitude and the need to decide immediately what kind of life we are to lead - a life of confession and repentance or, alternatively, a life immersed in idle diversions, deluded by the assumption that if one's life needs to be turned around at all, there is always more time ahead in which to do it. ${ }^{25}$ The notion of a call to decision is eschatological inasmuch as it encourages one to treat every moment as of final importance, to recognize that it is in this moment that one has the opportunity either to participate in the life of God or instead to remain preoccupied with the esteem of the world. When life is approached in this manner, then, as Dodd maintains, 'This world has become the scene of a divine drama, in which the eternal issues are laid bare' (1936b: 198).

There is, of course, much more to be said about the concept of realized eschatology, and more points will come out in the discussion below. What I have done so far is provide the gist, which will be elaborated as we turn to consider first some of the salient objections to this eschatological approach, and then some possible replies to those objections.

\section{Objections to Realized Eschatology}

Several types of objection are discernible in the critical literature on realized eschatology. Here, I shall outline the four that I take to be most prevalent, which I call the translation objection, the historical objection, the conceptual or definitional objection and the dilution objection, respectively.

The translation objection focuses on the use that Dodd and other proponents of realized eschatology make of a type of declaration that is attributed to Jesus in each of the synoptic gospels. In Mark 1:15 Jesus proclaims that 'The time is fulfilled, and the kingdom of God is at hand', and in Matthew 12:28 and Luke 11:20 he pronounces that 'the kingdom of God has come upon you'. Dodd would have no quarrel with these translations from the Revised Standard Version, since in each case-provided one

\footnotetext{
$\overline{25}$ 'The indolent youth speaks of a long life that lies before him. The indolent old man hopes that his death is still a long way off. But repentance and remorse belong to the eternal in a man. And in this way each time that repentance comprehends guilt it understands that the eleventh hour has come' (Kierkegaard 1956: 41). 'In the rush of busyness, one may be anxious over many things, begin many things, do many things at once, and only half do them all. But one cannot confess without [being at one] with oneself' (47).
} 
understands 'at hand' to mean 'here' rather than 'nearby' - they imply that the kingdom of God is not merely coming, but has already arrived. In Dodd's view, these verses constitute 'explicit and unequivocal' statements that Jesus regarded the kingdom or reign of God as having been realized during the time of his own ministry (Dodd 1936b: 49). The problem is that the Greek phrases in the above quotations that are rendered respectively as 'the kingdom of God is at hand' and 'the kingdom of God has come upon you' are amenable to alternative translations, and several scholars have contended that they are best understood as conveying not actual arrival or contact but rather acute proximity or nearness. ${ }^{26}$ A variant of this objection is the contention that although the translations preferred by Dodd may indeed be viable, the passages in question are far from unambiguous, making any claim that they provide conclusive proof one way or the other ill-advised. ${ }^{27}$

The historical objection questions the plausibility, or indeed the possibility, that Jesus himself or the earliest Christian communities accepted realized eschatology in the sense of a doctrine that locates salvation and the kingdom of God entirely in the present 'with no residue of futurity whatever' (Aune 1972: 6). Such a contention, David Aune maintains, 'is historically impossible, since all Christian eschatologies ... contain a dual emphasis on the present and future realization of the eschaton', albeit 'in widely varying proportions' (ibid.). This view, that what early Christianity preached is that the seed of God's action has been sown in the ministry of Jesus but will come to fruition in the imminent future, is widely endorsed by New Testament scholars and historians of Christianity; so widely, in fact, that it has been described as 'a growing consensus' (Ladd 1974: 3; cf. 38). ${ }^{28}$

The conceptual or definitional objection seeks to place in question the very intelligibility of realized eschatology by arguing that the concept of eschatology has futurity built into it. If one understands 'last things' (eschata) or 'the last thing' (eschaton) to be bound up with the end of history, then, the objection goes, a term such as 'realized eschatology' becomes oxymoronic, and 'futuristic eschatology' becomes a mere tautology (cf. Aune 1972: 1 fn.4). As A. W. Argyle puts it in response to the passage from Dodd that I used as one of the epigraphs of this article, 'the plain fact is that the eschaton cannot be moved from the future to the present (or to the past) and remain the eschaton, because the present and the past are before the end of history, and therefore not the end' (1952-1953a: 386; original emphasis). Thus, 'The question of definition is fundamental' (Ladd 1974: 40).

Finally, what I am calling the dilution objection overlaps to some extent with the conceptual objection, for it too contends that talk of realized eschatology is a misuse of

\footnotetext{
${ }^{26}$ See, e.g. Campbell (1936); Craig (1937); Clark (1940). For Dodd's reply to Campbell, see Dodd (1936a).

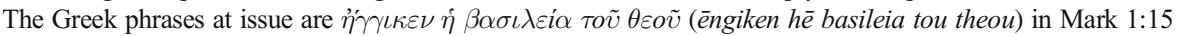

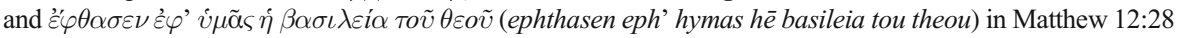
and Luke 11:20.

27 'The difficulty is that many of the discussions have failed to recognize the ambiguities both in the words themselves, and in the ideas which they convey' (Berkey 1963: 179).

${ }^{28}$ Cf. Kümmel (1963: 312): 'The experience of the present as the eschatological time of salvation and a burning anticipation of the impending eschatological completion of this salvation were fused into a composite view characteristic of the earliest Christian proclamation ...'. See also Berkey (1972: 73): '[T]here is a substantial majority of New Testament scholars who have accepted the fundamental substance of Dodd's thesis (i.e., presence of the Kingdom in the ministry of Jesus), while not necessarily moving on with Dodd to the rather drastic reappropriation of all future tenses'.
} 
eschatological vocabulary. But whereas the conceptual objection maintains that there is something straightforwardly self-contradictory or conceptually confused about 'realized eschatology', the dilution objection expresses the concern that it is indicative of a watering down of Christian concepts, such that the meaning of eschatology is in danger of being drowned in a sea of pseudo-eschatological verbiage. Two main forms of this objection are distinguishable, one of which can be termed the subjectivization objection and the other of which can be termed the jargon objection.

The subjectivization objection complains that in realized eschatology the idea of an objectively real transformation of history and of individual believers is replaced by a merely subjective or psychological conception. Complaints of this sort are prevalent in criticisms of Bultmann's theology, especially in response to his treatment of some of the major incidents associated with Jesus. With reference to the Gospel of John in particular, not only does Bultmann interpret Jesus' resurrection and parousía, along with the infusion of the Holy Spirit at Pentecost, as constituting a single event, but he takes this event to be 'an inner one' rather than 'an external occurrence'; ${ }^{29}$ it is 'the victory which Jesus wins' upon the arising of faith in those who recognize in him 'the Revelation of God' (Bultmann 1955: 57). Though Dodd, too, characterizes Christ's 'resurrection, exaltation, and second advent as being, in [the belief of the earliest Christians], inseparable parts of a single divine advent' (1944: 33) ${ }^{30}$ he does not conflate this divine advent quite as explicitly as does Bultmann with the 'inner' occurrence of the arising of faith. Critics of Bultmann characterize what they call his 'subjective existentialist interpretation' as resigning itself to 'a faith without hope'; for if resurrection and eternal life are internal to present faith itself, then there remains no 'future action of God', no 'life beyond the grave' or 'fulfillment of history beyond death' for which to be hopeful (Brunner 1954: 215, 214; cf. Hoye 2013: 68). What ends up being offered - as H. H. Price has said of the idea that 'eternal life' means nothing but 'life of the highest possible quality' - is 'a watered-down version of Christianity, in which the very idea of life after death is left out' (1972: 94).

The jargon objection is a complaint against those theologians who, by liberally deploying terms such as 'eschatology' and 'eschatological' in non-traditional ways, serve both to obfuscate their own meaning and to precipitate a devaluing of these terms more generally. Again one of the principal targets of this criticism has been Bultmann, who is prone to populate his prose with locutions such as 'the Church's eschatological understanding of itself' (1952: 43), 'eschatological consciousness of delimitation from the world' (106), 'eschatological de-secularization' $(107,163)$ and “"righteousness" ... in its forensic-eschatological sense' (276). It is alleged that by dislocating the term 'eschatological' 'from its strict meaning' in these ways, theology is turned into a technical idiom far removed from plain language (Argyle 1952-1953b: 306).

\footnotetext{
${ }^{29}$ The Greek term $\pi \alpha \rho$ ov $\sigma i \alpha$ (parousía), though often assumed to denote specifically a second coming, can also be defined simply as 'presence' or as 'the presence of one coming, hence the coming, arrival, advent' (Thayer 1901: 490).

${ }^{30}$ Cf. Dodd (1936b: 98): 'The developed theory allows for three stages: resurrection, exaltation, second advent; but there is some reason to think that at an early stage the two former were not distinguished, and in the saying in Mk. xiv. 62 the two latter are at least closely associated. Is it possible that all three are aspects of one idea?' (Curiously, in the 1961 edition, the final sentence of this passage begins 'It is' instead of 'Is it', and yet the question mark is retained.)
} 


\section{Replies to the Objections}

\section{Reply to the Translation Objection}

The translation objection is far from decisive against the interpretive claims of those who propound versions of realized eschatology, and I do not intend to dwell long upon it. Even if it is injudicious of Dodd to suggest that 'the sayings which declare the Kingdom of God to have come are explicit and unequivocal' (1936b: 49), the interpretive case does not rest exclusively on the sayings in question. Dodd's version of realized eschatology is based, at least in the first instance, on careful exegesis of numerous parables from the synoptic gospels, and Bultmann's existential approach draws heavily on John's writings and on the epistles of Paul, in which sources Bultmann detects early indications of a stripping away of the mythology that has tended to becloud the message of Jesus. ${ }^{31}$ The credibility of the view that Christian eschatology is best understood primarily, perhaps exclusively, in terms of a realization during the ministry of Jesus and in the faith of those who believe his gospel can, therefore, be neither established nor falsified purely on the basis of the few biblical verses on which the translation dispute has fixated.

\section{Reply to the Historical Objection}

Raising the historical objection in the way that Aune does, by claiming that the idea of an exclusively realized eschatology 'is historically impossible' because 'all Christian eschatologies' include a future as well as a present dimension, straightforwardly begs the question against the exclusively realized view, for it refuses to take this latter view seriously as itself a Christian eschatology. There clearly are and have been Christians who have interpreted the resurrection, exaltation and parousia of Christ not as events spread out over a long stretch of history, with the last of them being a happening that is still to come, but as events-or even as an event-already realized in the incarnation itself or in what Bultmann refers to as 'the believer's eschatological existence' (Bultmann 1955: 85 et passim).

Moreover, if the concept of realized eschatology were part of a purely descriptive thesis about what most Christians, especially the earliest Christians, have in fact believed, then the sort of historical point that Aune and others have raised would count against it. But the nature of the thesis is more complicated than that. It does, of course, have a descriptive aspect. Dodd argues, for example, that Jesus' parables, as recounted in the synoptic gospels, present us with the realized eschatology in which Jesus urged his disciples to believe; and Bultmann maintains not that Paul and John were devising purely imaginary accounts of Jesus as 'the eschatological salvation-bringer' (1955: 37),

\footnotetext{
31 'The decisive step was taken when Paul declared that the turning point from the old world to the new was not a matter of the future but did take place in the coming of Jesus Christ. ... After Paul, John de-mythologized the eschatology in a radical manner' (Bultmann 1958: 32, 33). Cf. Fergusson (1992: 96-97): 'As in Paul, we see in the fourth gospel a critique of traditional patterns of eschatological thought. ... This thoroughgoing demythologizing of a futurist eschatology is, for Bultmann, one of the theological gains of the fourth gospel'. For an alternative view of Paul, which regards him as more of an old-style apocalyptist than a realized eschatologist, see Käsemann (1969: 131-137) and Boring (1982: 112).
} 
but rather that they were disclosing a truth that tends to be obscured when surrounded by mythological narrative. There is, however, also a normative impulse behind the accounts that Dodd and Bultmann offer. Engaged in constructive theology at least as much as historiography, they are advocating an interpretation of Jesus' message that views it as a call to decision-a call to faith-and not as a prediction that the world is soon to end in an objective sense. Understood as a normative thesis, realized eschatology is not seriously damaged by claims about what many or most Christians have believed historically. And Aune's contention that a fully realized view is inconsistent with 'all Christian eschatologies' is an exaggeration.

\section{Reply to the Conceptual or Definitional Objection}

The claim that 'eschatology', by definition, implies futurity tends to underplay the broader teleological significance of the term. Talk of the eschaton or eschata can be construed as no less about purposes or final realities, in the sense of 'those things which possess finality and ultimacy of meaning' (Ladd 1974: 17), as about realities that are prophesied to eventuate in the future. Frederick Grant goes some way towards bringing out this distinction between futurity and finality when, following Dibelius, he characterizes 'the truth of the gospel' as being more about what is " "above" history ... in the everpresent "now" of eternity' than what is 'beyond' or after history (1950: 50); eschatology in this sense is 'suprahistorical', concerned with the culmination of the religious life rather than with the prediction of future events. ${ }^{32}$ Although Christ embodies the entry of God into history, the significance of this intervention is not to be awaited as history's climactic termination, but is to be responded to in the immediacy of the present.

\section{Reply to the Dilution Objection}

The subjectivization version of the dilution objection can be responded to in two main steps. The first consists in the denial that realized eschatology, even in its Bultmannian existentialist form, does involve a reduction of objectively real phenomena to features of human psychology. Although a strong emphasis is placed on the realization of the eschaton in the lives of believers, this realization is not an entirely subjective affair. The believer is called to respond to Jesus Christ, and neither the call itself nor the person of Christ is reducible to a merely subjective occurrence. The incarnation is 'God's eschatological act of salvation' (Bultmann 1952: 3), and it is in the encounter with Christ, as the Word of God, that the believer is enabled to respond (Bultmann 1964a: 204). The criticism frequently made of Bultmann that he has reduced theological to anthropological discourse, ${ }^{33}$ is therefore unfair, for he understands what is realized - made real - in the life of faith to come to fruition only in relationship with the divine; God, as revealed in Christ, is not a human invention, and

\footnotetext{
32 The term 'suprahistorical' occurs is Wrede (1971: 131) and also in the work of later authors, including Dodd (1938: 36). Grant (1950: 50; 1968: 113) picks it up from Dibelius, perhaps from Dibelius (1949: 70), where certain questions are referred to as 'superhistorical'.

33 See, e.g. Güttgemanns (1966: 199-206) and Bockmuehl (1988: 29-30).
} 
neither is 'divine incarnation' a 'metaphorical idea', as it is in Christologies that are genuinely dilutionary. ${ }^{34}$

But still, the condensation of the resurrection and parousia of Christ into a single event, which is in turn characterized as internal to faith rather than as 'an external occurrence' in the world, will strike many as flagrantly reductive. This is where the second step in the response to the subjectivization objection comes in. It points out that realized eschatology in this existentialist mode is not reducing eschatology to psychology; rather, it is providing an intensified and enriched conception of faith. As Bultmann among many other commentators has indicated, the content of eternal life — of 'eschatological existence' - as explicated especially in the Gospel and First Epistle of John unites faith with love and knowledge. 'Knowledge' is to be understood not as detached contemplation, but as a relationship with God - an acknowledgement of God's works and an ethical response of obedience to God's commandments. ${ }^{35}$ Chief among these commandments - indeed, what binds them together into a single commandment - is the obligation to love one another; in doing so, one not only obeys but also imitates God, for God has both issued the love commandment and, in Christ, epitomized it. ${ }^{36}$ When attention is paid to this conception of knowledge as communion and obedience, and to its integral connection with love and faith, then talk of something's arising in faith cannot be equated with its being a merely psychological state; it takes the form of active participation in the life of God. It is to the emergence of this active relationship that Bultmann refers when he speaks of the resurrection, exaltation and return of Christ being internal to faith. One can call this a dilution or a reduction if one likes; but if it is reductive in one sense (reducing an 'external' to an 'inner' occurrence), it is no less anti-reductive in another (enriching what we understand the 'inner' occurrence in question to consist in).

Meanwhile, the jargon version of the dilution objection grows out of the conceptual or definitional objection, inasmuch as it appeals to a narrow construal of the etymology of 'eschatology' in order to obviate or discredit more imaginative and wide-ranging applications of the term. Although Bultmann in particular may be guilty of somewhat overusing the adjective 'eschatological', his phraseology is not obscure within the context of his expanded conception of the meaning of eschatology. Talk of 'faith as eschatological existence', for example, draws upon what I, following others (such as Walls 2008a, 2010), have termed the teleological sense of 'eschatology' and coheres with the enriched notion of faith as active participation in the life of God to which I have referred above. Thus, while remaining wary of indiscriminate deployment of theological vocabulary, we should also be wary of attempts to regulate the use of terms in ways that unduly foreclose possibilities of conceptual augmentation.

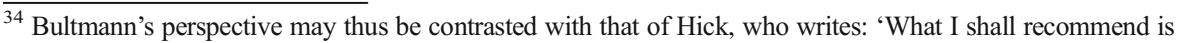
acceptance of the idea of divine incarnation as a metaphorical idea. We see in Jesus a human being extraordinarily open to God's influence and thus living to an extraordinary extent as God's agent on earth, “incarnating” the divine purpose for human life' (Hick 2005: 12).

${ }^{35}$ In this connection Bultmann (1964b) distinguishes the Hebraic from the Greek conception of knowledge. Dodd (1953: 152), following Bultmann, summarizes the distinction as follows: 'While for the Greek knowledge of God is the most highly abstract form of pure contemplation, for the Hebrew it is essentially intercourse with God; it is to experience His dealings with men in time, and to hear and obey His commands'. ${ }^{36}$ See esp. Bultmann (1955: 81-82). Illustrating 'the inner unity of indicative and imperative' moods in the commandment, Bultmann cites John 13:34, which reads: 'A new commandment I give you: to love each other as $(\kappa \alpha \theta \dot{\omega} \varsigma)$ I loved you, in order that you, too, should love each other' (English trans. by Kendrick Grobel from Bultmann's rendering of the Greek into German; Bultmann 1955: 81).
} 


\section{Concluding Remarks}

As I announced in the introduction, my purpose in this article has not been to defend realized eschatology as the truth about Jesus Christ and the message he is believed to have proclaimed. Rather, I have sought to elucidate this eschatological orientation by appraising some of its principal aspects. The orientation is not tightly constrained: it comes in different varieties. But in order to focus my discussion, I have concentrated for the most part on ideas from Dodd and Bultmann. Notwithstanding variations both within and between the work of these two eminent figures in twentieth-century theology and biblical exegesis, there are also deep affinities and synergies. Bultmann's existentialist analysis undoubtedly goes farther than Dodd in stressing the role of individual believers in engendering the raising and parousia of Christ through the vivacity of their response - in knowledge, faith and love - to Jesus' message; yet Dodd as well as Bultmann accentuates its being the response that is crucial to the eschaton's realization, as opposed to some cataclysmic cosmological event expected to occur subsequent to the crucifixion. In this respect, both thinkers supply means of avoiding the devastating conclusion of consistent eschatology-that Jesus' teachings were thoroughly embroiled with a false prediction, the 'monstrous illusion' of imminent world destruction. By offering, on its behalf, possible replies to objections that have been raised, I have argued for the coherence of realized eschatology as a meaningful religious perspective.

I suspect that many within the analytic philosophy of religion, with its prevalent assumption of a binary opposition between 'realism' and 'non-realism', will be inclined to pigeonhole realized eschatology as a form of nonrealism. This is likely to be especially true with respect to the conception of the resurrection and return of Christ as a single event, and of Bultmann's characterization of that event as internal to the life of faith, albeit an event that occurs only through encounter with the Word of God revealed as Christ himself. I hope to have indicated how this non-realist categorization can begin to be critically resisted. The arousal of a transformed life in the believer is not something 'non-real'; to the believer concerned, it is as real as anything can be. So what we face are different varieties of realism. On the one hand are realisms that imagine a man emerging from a tomb in which his own deceased body had been laid two or three days earlier and then, at some later time (a time that Jesus himself wildly miscalculated), coming back to earth after a period in heaven to usher in the kingdom of God. On the other hand are realisms that find the sense of the concept of the kingdom or reign of God in the life that Jesus lived, in the death that he suffered, and in the relationship with God that he makes possible. Talk of non-realism in this latter case, or of reducing or diluting the concept at issue, is an unilluminating distraction.

Realized eschatology is not a denial of divine realities; it is a dislocation —or rather, relocation - of those divine realities 'from the future to the present'. For Dodd, that present begins with the ministry of Jesus; for Bultmann, it seems, it is the ever-present moment of the believer's decisive commitment. In both cases, the call to decision is not a call to await some impending catastrophe at an unspecified point in the future: it is precisely the call to change one's life. It is in that moment of change, which must be constantly renewed, that the eschaton arrives. 
Acknowledgments Research for this article was carried out as part of my project entitled Immortality and Human Finitude: A Philosophical and Theological Study, which was supported by a sub-award from the Immortality Project (University of California, Riverside), funded by the John Templeton Foundation. The views expressed are those of the author and do not necessarily reflect those of either the Immortality Project or the John Templeton Foundation. A version of the article was presented at a Centre for Philosophy of Religion seminar at the University of Leeds, 19 February 2015. I am grateful to participants in that seminar for helpful comments and questions.

Open Access This article is distributed under the terms of the Creative Commons Attribution 4.0 International License (http://creativecommons.org/licenses/by/4.0/), which permits unrestricted use, distribution, and reproduction in any medium, provided you give appropriate credit to the original author(s) and the source, provide a link to the Creative Commons license, and indicate if changes were made.

\section{References}

Adams, M. M. (2006). Christ and horrors: the coherence of Christology. Cambridge: Cambridge University Press.

Argyle, A. W. (1952-1953). Does 'realized eschatology' make sense? Hibbert Journal, 51, 385-387.

Argyle, A. W. (1952-1953). Review of Rudolf Bultmann, Theology of the New Testament, Vol. 1. Hibbert Journal, 51, 305-306.

Aune, D. E. (1972). The cultic setting of realized eschatology in early Christianity. Leiden: Brill.

Barth, K. (1960). Church dogmatics (Vol. 3, Part 2). Edinburgh: Clark.

Barth, K. (1981). Letters, 1961-1968. Edinburgh: Clark.

Berkey, R. F. (1963). ЕГГIZEIN, $\Theta А A N E I N$, and realized eschatology. Journal of Biblical Literature, 82(2), 177-187.

Berkey, R. F. (1972). Realized eschatology and the post-Bultmannians. Expository Times, 84(3), 72-77.

Bible, The Holy: revised standard version (1971). National Council of Churches of Christ in the USA.

Bible, The: authorized King James version with apocrypha (1997 [1611]). Oxford: Oxford University Press.

Bockmuehl, K. (1988). The unreal God of modern theology: Bultmann, Barth, and the theology of atheism: a call to recovering the truth of God's reality. Colorado Springs: Helmers \& Howard.

Boring, M. E. (1982). Sayings of the risen Jesus: Christian prophecy in the synoptic tradition. Cambridge: Cambridge University Press.

Brunner, E. (1954). Eternal hope. London: Lutterworth Press.

Bultmann, R. (1952). Theology of the New Testament (Vol. 1). London: SCM Press.

Bultmann, R. (1955). Theology of the New Testament (Vol. 2). London: SCM Press.

Bultmann, R. (1958). Jesus Christ and mythology. New York: Scribner's Sons.

Bultmann, R. (1964). Bultmann replies to critics. In H.-W. Bartsch (Ed.), Kerygma and myth: a theological debate (Vol. 1, 2nd ed.) (pp. 191-211). London: SPCK.

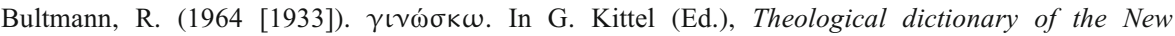
Testament (Vol. 1) (pp. 689-719). Grand Rapids, MI: Eerdmans.

Burley, M. (2009). Immortality and meaning: reflections on the Makropulos debate. Philosophy, 84, 529-547.

Burley, M. (2015). 'The end of immortality!' Eternal life and the Makropulos debate. Journal of Ethics, 19(3), 305-321.

Burley, M. (forthcoming). Eternal life as an exclusively present possession: perspectives from theology and the philosophy of time. Sophia. doi: 10.1007/s11841-015-0491-z

Burridge, R. A. (2007). Imitating Jesus: an inclusive approach to New Testament ethics. Grand Rapids: Eerdmans.

Bush, G. (1845). Anastasis: or the doctrine of the resurrection of the body, rationally and scripturally considered. New York: Wiley.

Campbell, J. Y. (1936). Contributions and comments. Expository Times, 48(2), 91-94.

Caragounis, C. C. (2001). The kingdom of God: common and distinct elements between John and the synoptics. In R. T. Fortna \& T. Thatcher (Eds.), Jesus in the Johannine tradition (pp. 125-134). Louisville: Westminster John Knox Press.

Chappell, T. (2009). Infinity goes up on trial: must immortality be meaningless? European Journal of Philosophy, 17(1), 30-44. 
Citron, G. (2012). 'What's ragged should be left ragged': a Wittgensteinian investigation into the 'messiness' of religious beliefs and utterances. Ph.D. thesis, University of Oxford.

Citron, G. (2013). Religious language as paradigmatic of language in general: Wittgenstein's 1933 lectures. In N. Venturinha (Ed.), The textual genesis of Wittgenstein's 'Philosophical Investigations' (pp. 19-36). New York: Routledge.

Clark, K. W. (1940). 'Realized eschatology'. Journal of Biblical Literature, 59(3), 367-383.

Craig, C. T. (1937). Realized eschatology. Journal of Biblical Literature, 56(1), 17-26.

Crossan, J. D. (1998). The birth of Christianity: discovering what happened in the years immediately after the execution of Jesus. New York: HarperCollins.

Davis, S. T. (1998). Eschatology. In E. Craig (Ed.), Routledge encyclopedia of philosophy (Vol. 3, pp. 413-417). London: Routledge.

Dhavamony, M. (1999). Hindu spirituality. Rome: Editrice Pontificia Universita' Gregoriana.

Dibelius, M. (1949 [1939]). Jesus. Philadelphia, PA: Westminster Press.

Dobschütz, E. von (1910). The eschatology of the gospels. London: Hodder and Stoughton.

Dodd, C. H. (1936a). Contributions and comments. Expository Times, 48(3), 138-142.

Dodd, C. H. (1936b). The parables of the kingdom. London: Nisbet.

Dodd, C. H. (1938). History and the Gospel. London: Nisbet.

Dodd, C. H. (1944). The apostolic preaching and its developments: three lectures with an appendix on eschatology and history (new ed.). London: Hodder \& Stoughton.

Dodd, C. H. (1953). The interpretation of the fourth gospel. Cambridge: Cambridge University Press.

Dodd, C. H. (1961). The parables of the kingdom (rev. ed.). London: Nisbet.

Ellis, E. E. (1965). Present and future eschatology in Luke. New Testament Studies, 12(1), $27-41$.

Farelly, N. (2010). The disciples in the fourth gospel: a narrative analysis of their faith and understanding. Tübingen: Mohr Siebeck.

Fergusson, D. (1992). Bultmann. Collegeville: Liturgical Press.

Fischer, J. M., \& Mitchell-Yellin, B. (2014). Immortality and boredom. Journal of Ethics, 18(4), 353-372.

Florovsky, G. (1972). Bible, church, tradition: an Eastern Orthodox view. Belmont: Nordland.

Forestell, J. T. (1974). The word of the cross. Rome: Biblical Institute Press.

Fuller, R. H. (1954). The mission and achievement of Jesus: an examination of the presuppositions of New Testament theology. London: SCM Press.

Grant, F. C. (1950). An introduction to New Testament thought. New York: Abingdon-Cokesbury Press.

Grant, F. C. (1968). Psychological study of the Bible. In J. Neusner (Ed.), Religions in antiquity: essays in memory of Erwin Ramsdell Goodenough (pp. 107-124). Leiden: Brill.

Güttgemanns, E. (1966). Der leidende Apostel und sein Herr: Studien zur paulinischen Christologie. Göttingen: Vandenhoeck \& Ruprecht.

Hanson, P. D. (1979). Dawn of apocalyptic: historical and sociological roots of Jewish apocalyptic eschatology (2nd ed.). Minneapolis: Fortress Press.

Harkness, G. (1974). Understanding the kingdom of God. Nashville: Abingdon.

Hebblethwaite, B. (1979). Time and eternity and life 'after' death. Heythrop Journal, 20(1), 57-62.

Hick, J. (1966). Faith and knowledge (2nd ed.). Ithaca: Cornell University Press.

Hick, J. (2005). The metaphor of God incarnate: Christology in a pluralistic age (2nd ed.). London: SCM Press.

Hiltebeitel, A. (1972). The 'Mahābhārata' and Hindu eschatology. History of Religions, 12(2), 95-135.

Hitchcock, N. (2013). Karl Barth and the resurrection of the flesh: the loss of the body in participatory eschatology. Eugene: Wipf and Stock.

Hoye, W. J. (2013). The emergence of eternal life. Cambridge: Cambridge University Press.

Hunter, A. M. (1973). The work and words of Jesus (rev. ed.). London: SCM Press.

Käsemann, E. (1969 [1965]). New Testament questions of today. London: SCM Press.

Kierkegaard, S. (1956 [1847]). Purity of heart is to will one thing: spiritual preparation for the office of confession. New York: Harper \& Row.

Kümmel, W. G. (1959). Futurische und Präsentische Eschatologie im Ältesten Urchristentum. New Testament Studies, 5(2), 113-126.

Kümmel, W. G. (1963). Futuristic and realized eschatology in the earliest stages of Christianity. Journal of Religion, 43(4), 303-314.

Ladd, G. E. (1974). The presence of the future: the eschatology of biblical realism (rev. ed.). Grand Rapids: Eerdmans.

Manson, T. W. (1931). The teaching of Jesus. Cambridge: Cambridge University Press.

Martin, H. V. (1939). Proleptic eschatology. Expository Times, 51(2), 88-90.

McGrath, A. E. (2011). Christian theology: an introduction (5th ed.). Malden: Wiley-Blackwell. 
Muirhead, L. A. (1904). The eschatology of Jesus; or, the kingdom come and coming: a brief study of our Lord's apocalyptic language in the synoptic gospels. New York: Armstrong \& Son.

Obeyesekere, G. (1980). The rebirth eschatology and its transformations: a contribution to the sociology of early Buddhism. In W. Doniger O'Flaherty (Ed.), Karma and rebirth in classical Indian traditions (pp. 137-164). Berkeley: University of California Press.

Otto, R. (1934). Reich Gottes und Menschensohn: Ein religionsgeschichtlicher Versuch. München: Beck.

Owen, H. P. (1959). The parousia of Christ in the synoptic gospels. Scottish Journal of Theology, 12(2), 171-192.

Oxford English Dictionary (2013). Online version. Oxford: Oxford University Press.

Philipse, H. (2012). God in the age of science? A critique of religious reason. Oxford: Oxford University Press.

Phillips, D. Z. (1970). Death and immortality. London: Macmillan.

Price, H. H. (1972). Essays in the philosophy of religion. Oxford: Clarendon.

Rahner, K. (1966). Theological investigations (Vol. 4). London: Darton, Longman \& Todd.

Rahner, K. (1975). Theological investigations (Vol. 13). London: Darton, Longman \& Todd.

Rahner, K. (1986). What do I mean when I say: life after death? Radio interview, 20 February 1972. In P. Imhof \& H. Biallowons (Eds.), Karl Rahner in dialogue: conversations and interviews, 1965-1982 (pp. 85-92). New York: Crossroad.

Ridderbos, H. (1975 [1966]). Paul: an outline of his theology. Grand Rapids, MI: Eerdmans.

Robinson, J. A. T. (1957). Jesus and his coming: the emergence of a doctrine. London: SCM Press.

Rowe, W. L. (1984). Evil and the theistic hypothesis: a response to Wykstra. International Journal for Philosophy of Religion, 16(2), 95-100.

Russell, B. (1957). Why I am not a Christian and other essays on religion and related subjects. London: Allen \& Unwin.

Schleiermacher, F. (1958 [1799, 3rd ed. 1821]). On religion: speeches to its cultured despisers. New York: Harper \& Row.

Schweitzer, A. (1906). Von Reimarus zu Wrede. Eine Geschichte der Leben-Jesu-Forschung. Tübingen: Mohr Siebeck.

Schweitzer, A. (1911 [1906]). The quest of the historical Jesus: a critical study of its progress from Reimarus to Wrede (2nd ed.). London: Black.

Schweitzer, A. (1914). The mystery of the kingdom of God: the secret of Jesus' messiahship and passion. New York: Dodd, Mead and Company.

Sharman, H. B. (1909). The teaching of Jesus about the future according to the synoptic gospels. Chicago: University of Chicago Press.

Smith, J. I., \& Haddad, Y. Y. (1981). The Islamic understanding of death and resurrection. Albany: State University of New York Press.

Stump, E. (2010). Wandering in darkness: narrative and the problem of suffering. Oxford: Oxford University Press.

Sullivan, C. (1988). Rethinking realized eschatology. Macon: Mercer University Press.

Swinburne, R. (2008). Was Jesus God? Oxford: Oxford University Press.

Taylor, J. B. (1968). Some aspects of Islamic eschatology. Religious Studies, 4(1), 57-76.

Thayer, J. H. (Ed.). (1901). A Greek-English lexicon of the New Testament: being Grimm's Wilke's Clavis Novi Testamenti (4th ed.). Edinburgh: Clark.

Wainwright, W. J. (2013). Christianity. In C. Taliaferro, V. S. Harrison, \& S. Goetz (Eds.), The Routledge companion to theism (pp. 54-65). New York: Routledge.

Walls, J. L. (Ed.). (2008a). The Oxford handbook of eschatology. Oxford: Oxford University Press.

Walls, J. L. (2008b). Introduction. In J. L. Walls (Ed.), The Oxford handbook of eschatology (pp. 3-18). Oxford: Oxford University Press.

Walls, J. L. (2010). Eschatology. In C. Taliaferro \& E. J. Marty (Eds.), A dictionary of philosophy of religion (pp. 78-79). New York: Continuum.

Weiss, J. (1971 [1892]). Jesus' proclamation of the kingdom of God. London: SCM Press.

Williams, B. (1973). The Makropulos case: reflections on the tedium of immortality. In his Problems of the self (pp. 82-100). Cambridge: Cambridge University Press.

Windisch, H. (1951). The meaning of the sermon on the mount: a contribution to the historical understanding of the gospels and to the problem of their true exegesis. Philadelphia: Westminster Press.

Wittgenstein, L. (1980). Culture and value. Oxford: Blackwell.

Wondra, O. C., \& Wondra, E. K. (2002). Introduction to theology (3rd ed.). Harrisburg: Morehouse.

Wrede, W. (1971 [1901]). The messianic secret. Cambridge: Clarke.

Zürcher, E. (1982). 'Prince moonlight': messianism and eschatology in early medieval Chinese Buddhism. T'oung Pao, Second Series, 68(1-3), 1-75. 